\title{
Induksi anastesi menggunakan Ket-A-Xyl@ pada kucing domestik
}

\author{
Dwi Utari Rahmiati*, Dwi Wahyudha Wira \\ Program Studi Kedokteran Hewan, Universitas Padjadjaran, Jatinangor, Bandung
}

\begin{abstract}
ABSTRAK: Kombinasi Ketamine dan Xylazine sebagai induksi anastesi sangat umum digunakan pada hewan kecil. Protokol pemberiannya umumnya didahului dengan pemberian Atropin sulfat sebagai premedikasi yang diberikan secara tersendiri. Produk baru yang berisi kombinasi ketamine, atropine dan xylazine (Ket-A-Xyl ${ }^{\circledR} 20 \mathrm{ml}$, AgroVet, Peru) telah dipasarkan di Indonesia untuk induksi anastesi pada anjing. Penelitian ini bertujuan untuk menilai efek induksi anastesi sediaan Ket-A-Xyl pada kucing domestik. Hasil pemberian sediaan ini pada kucing domestik memiliki onset $3.33 \pm 2.07$ menit dan durasi $59.5 \pm$ 11.11 menit. Induksi dengan sediaan ini menimbulkan efek anastesi yang berlangsung sangat halus, tenang, tidak menimbulkan muntah serta memiliki efek muscle relaxant yang baik. Hewan coba sebagian besar tidak menunjukkan adanya delirium. Sediaan Ket-A-Xyl® dinilai efisien dalam mengurangi waktu yang diperlukan pada fase preanastesi meskipun efek hipotermia terjadi pada seluruh hewan.
\end{abstract}

Kata kunci:

atropine, durasi, ketamine, onset, xylazine

\section{- PENDAHULUAN}

Kombinasi ketamine dan zylazine secara intramuskular telah digunakan sejak 1979 sebagai induksi anastesi pada kucing (Arnbjerg 1979). Kombinasi keduanya dinilai efektif sebagai sediaan yang mampu menghilangkan kesadaran dan menimbulkan efek muscle relaxant yang baik. Akan tetapi, efek samping dari kombinasi keduanya pada kucing adalah hipotermia, penurunan frekuensi denyut jantung, frekuensi pernapasan, cardiac output, serta tekanan darah (Allen et al. 1986). Atropin digunakan sebagai premedikasi yang bertujuan untuk mengatasi efek depresi yang ditimbulkan dari sediaan anastesi. Atropin berfungsi mencegah sekresi bronkial dan saliva, mencegah muntah serta meningkatkan denyut jantung (Lemke 2007). Atropin sebagai premedikasi umumnya diberikan 20 menit sebelum pemberian anastesi kombinasi ketamine dan xylazine (Lemke 2007).

Produk baru yang berisi kombinasi ketamine, atropine dan xylazine (Ket-A-Xyl® $20 \mathrm{ml}$, AgroVet, Peru) telah dipasarkan di Indonesia untuk induksi anastesi pada anjing. Sediaan tersebut mengandung ketamine $\mathrm{HCl} 100 \mathrm{mg}$, atropin $1 \mathrm{mg}$ dan xylazine $20 \mathrm{mg} \mathrm{HCl}$ dalam setiap $1 \mathrm{ml}$. Produk ini mampu memberikan hasil anastesi yang lebih baik, mengurangi efek samping. Indikasi penggunaan pada induksi serta maintenance anastesi dalam prosedur bedah ovariohisterektomi, kastrasi, sectio caesaria, laparotomi, pencabutan gigi serta operasi mata. Produk ini memiliki anjuran pemakaian yaitu $0.5-1 \mathrm{ml} / 10 \mathrm{~kg}$ bobot badan dengan rute intramuskular. Informasi penggunaan sediaan ini pada kucing domestik hingga saat ini belum tersedia.

\section{- MATERI DAN METODE}

Percobaan ini menggunakan 6 ekor kucing domestik jantan dengan berat badan berkisar 3,5 - 4,2 kg. Semua kucing diperiksa suhu, frekuensi denyut jantung, frekuensi pernapasan, capillary refill time serta kondisi mukosa sebelum dilakukan diinduksi anastesi. Dosis sediaan Ket-A-Xyl® (AKX) yang digunakan pada penelitian ini adalah $1 \mathrm{ml} / 10$ $\mathrm{kg} \mathrm{BB}$ dengan rute pemberian secara intramuskular. Onset dan durasi serta pengamatan perubahan aktivitas dan pergerakan pada hewan diamati dan dicatat.

\section{- HASIL DAN PEMBAHASAN}

Gejala yang timbul dari pemberian AKX pada 6 ekor kucing jantan domestik selama onset adalah hewan tenang, tidak terjadi muntah serta menghasilkan muscle relaxant yang baik. Onset anastesi setelah pemberian AKX adalah $3,33 \pm 2,07$ menit (Tabel 1). Onset hasil penggunaan AKX berlangsung lebih singkat 20 menit dibanding dengan penggunaan atropin sebagai premedikasi secara terpisah dari anastesi $(\mathrm{A}+\mathrm{KX})$. Hal ini disebabkan karena atropin secara tersendiri akan mencapai puncak efek sekitar 10-20 menit (Lemke 2007). Rata-rata onset setelah induksi kombinasi ketamine dan xylazine pada kucing domestik adalah $60,00 \pm 10,58$ detik secara intravena (Yusuf et al. 2018) dan $9,67 \pm 1,211$ menit secara intramuskular (Nesgash et al. 2016).
Diterima: 11-07-2019 | Direvisi: 10-08-2019 | Disetujui: 17-08-2019 (C) 2019 CC-BY-SA. Ini adalah artikel Open Access yang didistribusikan berdasarkan ketentuan dari Creative Commons Attribution ShareAlike 4.0 International License (https://creativecommons.org/licenses/by-sa/4.0/). 
Table 1 Onset dan durasi pemberian Ket-A-Xyl® pada kucing jantan domestik

\begin{tabular}{|c|c|c|c|}
\hline $\begin{array}{c}\text { Berat Badan } \\
\text { (Kg) }\end{array}$ & $\begin{array}{c}\text { Volume } \\
(\mathbf{m l})\end{array}$ & $\begin{array}{c}\text { Onset } \\
\text { (menit) }\end{array}$ & $\begin{array}{c}\text { Durasi } \\
\text { (menit) }\end{array}$ \\
\hline 3,40 & 0,34 & 3,00 & 61,00 \\
3,60 & 0,36 & 1,00 & 66,00 \\
3,40 & 0,34 & 4,00 & 48,00 \\
4,20 & 0,42 & 7,00 & 44,00 \\
3,80 & 0,38 & 3,00 & 67,00 \\
3,50 & 0,35 & 2,00 & 71,00 \\
\hline $3,65 \pm 0,31$ & $0,37 \pm 0,03$ & $3,33 \pm 2,07$ & $59,5 \pm 11,11$ \\
\hline
\end{tabular}

Durasi anastesi setelah pemberian AKX adalah $59,5 \pm 11,11$ menit. Waktu durasi anastesi ini serupa dengan

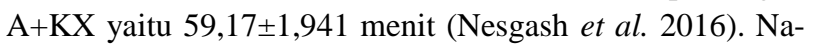
mun durasi anastesi AKX dalam penelitian ini lebih singkat dibandingkan $\mathrm{A}+\mathrm{KX}$ secara intravena yaitu 72,28 \pm 3,95 menit (Yusuf et al. 2018). Frekuensi denyut jantung tidak mengalami perubahan signifikan setelah pemberian AKX, sedangkan frekuensi pernapasan dan suhu mengalami perubahan signifikan $(p<0,05)$ (Tabel 2).

Tabel 2 Parameter fisiologis setelah induksi Ket-A-Xyl® pada kucing jantan domestik

\begin{tabular}{|c|c|c|c|c|c|c|}
\hline $\begin{array}{c}\text { Bobot } \\
\text { Badan } \\
\text { (Kg) }\end{array}$ & $\begin{array}{c}\text { FJ } \\
(/ \mathbf{m n t})\end{array}$ & $\begin{array}{c}\text { FJ' } \\
(/ \mathbf{m n t})\end{array}$ & $\begin{array}{c}\text { FR } \\
(/ \mathrm{mnt})\end{array}$ & $\begin{array}{c}\text { FR' } \\
(/ \mathbf{m n t})\end{array}$ & $\mathrm{T}\left({ }^{\circ} \mathrm{C}\right)$ & $\mathrm{T}^{\prime}\left({ }^{\circ} \mathrm{C}\right)$ \\
\hline 3,4 & 172 & 200 & 56 & 28 & 38,5 & 39,1 \\
\hline 3,6 & 140 & 120 & 68 & 36 & 37,0 & 35,8 \\
\hline 3,4 & 100 & 104 & 44 & 24 & 38,1 & 36,0 \\
\hline 4,2 & 124 & 120 & 28 & 28 & 38,4 & 35,4 \\
\hline 3,8 & 108 & 112 & 32 & 28 & 38,0 & 34,3 \\
\hline 3,5 & 128 & 120 & 20 & 16 & 38,0 & 37,5 \\
\hline $3,7 \pm 0,3$ & $128,7 \pm 25,6$ & $129,3 \pm 35,2$ & $41,3 \pm 18,2$ & $26,7 \pm 6,5$ & $38,0 \pm 0,5$ & $36,4 \pm 1,7$ \\
\hline Nilai p & $\overline{0,9}$ & & $\mathbf{0 , 0 4}$ & $48 *$ & 0 & $48 *$ \\
\hline
\end{tabular}

FJ: Frekuensi denyut jantung sebelum induksi, FJ': frekuensi denyut jantung 15 menit setelah induksi, FR: frekuensi pernapasan sebelum induksi, FR': frekuensi respirasi 15 menit setelah induksi. T: suhu sebelum induksi. T': suhu 15 menit setelah induksi. *menunjukkan nilai yang signifikan.

Suhu normal kucing berkisar $38,6{ }^{\circ} \mathrm{C}$, frekuensi denyut jantung yaitu 140-210 kali per menit, frekuensi pernapasan yaitu 20-24 kali per menit (Morgan 2008). Frekuensi denyut jantung kucing dengan pemberian anastesi AKX menunjukkan perubahan nilai yang tidak seragam. Denyut jantung 3 ekor kucing mengalami peningkatan, dan 3 ekor lainnya menunjukkan penurunan. Hal ini berbeda dengan hasil penggunaan anastesi $\mathrm{A}+\mathrm{KX}$ yang umumnya mengalami peningkatan denyut jantung (Nesgash et al. 2016). Frekuensi pernapasan kucing dengan pemberian anastesi AKX menunjukkan penurunan dibandingkan sebelumnya $(\mathrm{p}<0,05)$. Efek ini serupa dengan metode anastesi A+KX (Nesgash et al. 2016). Suhu kucing dengan pemberian AKX juga mengalami penurunan yang serupa dengan frekuensi napas $(p<0,05)$. Hal ini sedikit berbeda dengan kucing dengan pemberian $\mathrm{A}+\mathrm{KX}$ dimana suhu kucing hanya sedikit mengalami peningkatan pascaanastesi (Nesgash et al. 2016).

Onset dan respon kucing pascaanastesi menunjukkan bahwa sediaan AKX lebih efisien dibandingkan metode anastesi $\mathrm{A}+\mathrm{KX}$. Namun jika dibandingkan dengan pembe- rian $\mathrm{A}+\mathrm{KX}$ dengan rute intravena berdasarkan onset dan durasi, maka sediaan AKX tidak menunjukkan hasil yang lebih baik. Sediaan anastesi AKX dan A+KX menunjukkan perubahan yang serupa pada parameter frekuensi denyut jantung, frekuensi pernapasan serta suhu.

\section{- SIMPULAN}

Sediaan anastesi Ket-A-Xyl® berpotensi sebagai induksi anastesi pada kucing domestik karena lebih efisien, onset singkat dan durasi medium, serta menimbulkan respon yang ringan selama onset.

\section{- INFORMASI PENULIS}

Penulis untuk Korespondensi

*DUR: dwi.utari@unpad.ac.id

Program Studi Kedokteran Hewan, Fakultas Kedokteran, Universitas Padjadjaran, Jatinangor, Bandung.

\section{- UCAPAN TERIMA KASIH}

Penulis mengucapkan terima kasih kepada Universitas Padjadjaran melalui pendanaan perjalanan dosen periode Agustus 2019 yang digunakan selama penelitian ini.

\section{- PUSTAKA ACUAN}

Allen DG, Dyson DH, Pascoe PJ, O'Grady MR. 1986. Evaluation of a xylazine-ketamine hydrochloride combination in the cat. Canadian Journal of Veterinary Research. 50(1): 23-26

Arnbjerg J. 1979. Clinical use of ketamine-xylazine for anaesthesia in the cat. Nordisk veterinaermedicin. 31(4):145-54

Lemke KA. 2007. Anticholinergics and Sedatives. di dalam Lumb \& Jones Veterinary Anesthesia and Analgesia. $4^{\text {th }}$ edition. Tranquilli WJ, Thurman JC, Grimm KA, editor. Iowa (US): Blackwell. Pp: 203-205

Morgan RV. 2008. Appendix I: Normal Physiologic Values. Di dalam: Handbook of Small Animal Practice. $5^{\text {th }}$ edition. Missouri (US): Elsevier. Pp: 1272

Nesgash A, Yaregal B, Kindu T, Hailu E. 2016. Evaluation of general anesthesia using xylazine-ketamine combination with and without diazipam for ovariohyterectomy in bitches. Journal of Veterinary Science \& Technology. 7(6): 1000376

Yusuf MC, Syafruddin, Roslizawaty. 2018. Pengaruh ketaminexylazin terhadap onset dan sedasi kucing lokal (Felis catus) yang diovariohisterektomi. Jurnal Ilmiah Mahasiswa Veteriner. 2(4): 599-603 